Britain in July 1949, under the presidency of Sir Henry Tizard. The chief object of the Congress is to afford an opportunity for scientific men, engineers and others concerned with the mining and metallurgical industries to meet and discuss technical progress and problems, including the development of the mineral resources of the Commonwealth. The programme will be divided into three parts: July 9-12, inaugural meeting, official functions, exhibitions, visits, etc., in London ; July 13-17, technical sessions in Oxford; July 18-23, excursions based for the most part on universities in Great Britain. Further information can be obtained from the General Secretaries, Fourth Empire Mining and Metallurgical Congress, 436 Salisbury House, Finsbury Circus, London, E.C.2.

\section{Colonial Medical Research Fellowships}

THE Secretary of State for the Colonies has instituted a limited number of research studentships for graduates in medicine and cognate sciences, who desire by this means to prepare themselves for research work in tropical medicine and related subjects. They will be awarded on the advice of the Colonial Medical Research Committee, and will be tenable for two years at any university or other appropriate institution as approved by the Committee. The maximum rates of allowance payable are $£ 300$ per annum at the Universities of Oxford, Cambridge and London, and $£ 260$ per annum at other universities in the United Kingdom. Candidates must be British subjects and graduates of British universities. Application should be made, through the head of the candidate's Department, to the Secretary, Colonial Medical Research Committee, c/o Research Department, Colonial Office, Sanctuary Buildings, Gt. Smith Street, London, S.W.I, and should include, in addition to details of the candidate's academic record, some indication of the subject preferred.

\section{A General Solution for the Force Constants of Polyatomic Molecules}

Mr. P. Torkingron writes with reference to the communication under the above title in Nature of September 4, p. 370: "It was stated that in the proposed solution the normal co-ordinate for $v_{i}$ involved only the co-ordinates $\Delta_{i}$ to $\Delta_{n}$. In fact, it involves only the co-ordinates $\Delta_{1}$ to $\Delta_{i}$. The linear transformation giving the (unnormalized) normal co-ordinates $\eta_{i}$ is found to be

$$
\eta_{i}=\sum_{j=1}^{i}\left({ }^{i}|A|_{i j}\right) \Delta_{j} .
$$

The quantities on the right-hand side of equations (7) and (8) are coefficients in the reverse transformation, giving here the components in the displacement for $v_{k}$ in terms of $\eta_{k}$. In (8), the coefficients for $\Delta_{1}$ to $\Delta_{k-1}$ are zero; it is therefore the form of the vibration, not the normal co-ordinate, which involves $\Delta_{k}$ to $\Delta_{n}$ only. Where $\left(v_{i}-v_{i+1}\right)$ is small, and $\Delta_{i}$ and $\Delta_{i+1}$ overlap, $\eta_{i}$ would be expected to involve $\Delta_{i+1}$; $\eta_{i+1}$ involves $\Delta_{i}$ in any event."

\section{Announcements}

Tew Lords Commissioners of the Treasury have appointed Dr. A. E. Trueman to be chairman of the University Grants Committee in succession to $\mathrm{Sir}$ Walter Moberly, who retires on October 1, 1949. Dr. Trueman, who has had a distinguished career as a geologist and a university administrator, became deputy chairman of the Committee in 1946 (see Nature, August 31, 1946, p. 299).

Dr. Robert CRUTCKshanK, since 1945 director of the Central Public Health Laboratory of the Public Health Laboratory Service, has been appointed to the chair of bacteriology tenable at St. Mary's Hospital Medical School, London, as from January 1, 1949.

DR. R. A. M. CASE, until recently a principal scientific officer in the Royal Naval Scientific Service at the Royal Naval Physiological Laboratory, has taken up appointment at the Chester Beatty Research Institute of the Royal Cancer Hospital as research fellow under a scheme inaugurated by the Association of British Chemical Manufacturers, for the field and experimental investigation of the industrial incidence of papilloma of the bladder.

Dr. T. T. Paterson, who has resigned his post as curator of the Museum of Archæology and Ethnology, Cambridge (see Nature, September 18, p. 445), is to devote his time to research in the social anthropology of Britain, with special reference to problems of social medicine and group phenomena in the industrial, rural and urban fields. The investigation is being financed by a grant from the Medical Research Council.

THE Leon Gaster Memorial Premium of the Illuminating Engineering Society, given annually for the best contribution submitted to and published by the Society during the session, has this year been awarded to Mr. J. N. Bowtell and Mr. H. G. Jenkins for their paper entitled "High Voltage Fluorescent Tubes". In view of the high standard of papers eligible for the award this year, the Council has made a second award to Messrs. H. K. Cameron, E. H. Rayner, E. R. Thomas and G. T. Winch for their paper entitled "Photometry of Searchlights" which forms part of the "Symposium on Searehlights" recently published by the Illuminating Engineering Society.

THE Tilden Lecture of the Chemical Society will be delivered by Prof. C. E. H. Bawn in the rooms of the Society on November 11 at 7 p.m. Prof. Bawn will speak on "The Structure and Reactivity of Free Radicals".

A COURSE of eight lectures on practical psychical research, beginning on October 16, has been arranged by the Society for Psychical Research and will be given at its house, 31 Tavistock Square, London, W.C.1. The topics to be discussed include the investigation of cases, extra-sensory perception experiments, and psychological and statistical methods. Tickets of admission (one ticket covers the whole course) can be obtained free from the secretary of the Society.

DR. B. P. DUDDING, honorary lecturer in industrial statistics, University of Sheffield, will give a course of eight lectures at the Sir John Cass Technical Institute, London, E.C.3, on Monday evenings at 7 p.m., beginning on October 25, on "Statistical Methods in Industry". A further course of lectures, also on Mondays at 7 p.m., beginning January 24, will be given by Mr. K. A. Brownlee on "Design of Experiments". The fee for either course is $£ 1$. Application for enrolment forms should be made to the Principal of the Institute prior to the opening date of the courses. 